\title{
Soybean Oil and Beef Tallow in Starter Broiler Diets ${ }^{1}$
}

\section{Author(s)}

Fascina $V^{2}$

Carrijo $A S^{3}$

Souza KMR2

Garcia $\mathrm{AML}^{2}$

Kiefer $\mathrm{C}^{3}$

Sartori $\mathrm{JR}^{4}$

Part of the M. Sc. dissertation of the first author. Project funded by FUNDECT-MS (Process: 41/100.246/2005).

2 M. Sc. Student of the Post-Graduation Program in Animal Science, FAMEZ/UFMS. Grant by FUNDECT-MS.

3 Professor, Ph.D, Departamento de Zootecnia da Faculdade de Medicina Veterinária e Zootecnia da Universidade Federal de Mato Grosso do Sul - Campo Grande/MS, Brazil.

4 Associate Professor, PH.D., Departamento de Melhoramento e Nutrição Animal, FMVZ, UNESP/Botucatu.

\section{Mail Address}

\section{Vitor Barbosa Fascina}

Departamento de Zootecnia

FAMEZ, UFMS/Campo Grande

Av. Felinto Muller, 2443

79070-900. Campo Grande, MS, Brazil

E-mail: vitorfascina@yahoo.com.br

\section{ABSTRACT}

The objective of this study was to determine the energy values of soybean oil (SBO) and tallow (T) combined in different ratios, and to evaluate their effects on the performance, body composition, and serum lipid levels of starter broilers. In experiment I, a digestibility trial was performed to determine the energy value of the $\mathrm{SOB}$ and $\mathrm{T}$ mixtures using 10012 - to 21 -day-old broilers. In experiment II, 930 one-day-old broilers were used. Treatments consisted of the inclusion of $4 \%$ SBO and T inclusions at the following ratios: 0:100, 25:75, 50:50, 75:25, 100:0. Each treatment included six replicates. In experiment I, AME and AMEn linearly increased $(P<0.01)$, as SBO participation in the mixture increased. In experiment II, the different lipid ratios quadratically influenced $(P<0.01)$ body weight and weight gain at 21 days of age, increasing up to the ratio of 65.87:34.13. Serum lipids linearly decreased $(P<0.05)$ as SOB inclusion in the diet increased. It was concluded that AME and AMEn of SBO and $T$ at ratios of 0:100, 25:75, 50:50, 75:25, and 100:0 were 7.882 and $7.542,8.384$ and 8.076, 8.701 and 8.385, 8.801 and 8.727, and 9.478 and $9.271 \mathrm{kcal} / \mathrm{kg}$, respectively. The best performance with no detrimental effect on carcass yield was obtained with the mixture of $75 \%$ SBO with $25 \% \mathrm{~T}$. The highest dietary soybean oil level reduced serum lipid levels of 21-day-old broilers.

\section{INTRODUCTION}

The use of vegetable oils and animal fats in broiler diets has been beneficial for poultry production. They often present higher than expected biological value, increasing dietary metabolizable energy, which usually results in higher growth rates and better feed efficiency.

The main factor that influences the nutritional value of fat sources is digestibility, which is affected by fatty acid saturation degree, carbon number in the chain, free fatty acid concentration, position of the glycerol molecule, as well as the interaction between saturated and unsaturated fatty acids (Rener \& Hill, 1961; Ketels \& DeGroote, 1989; Dvorin et al., 1998; Leeson \& Summers, 2001).

Dvorin et al. (1998) showed that the energy values of fat sources by mixture with vegetable oils due to interaction between saturated and unsaturated fatty acids, provided the fatty acids present in the mixture are balanced.

Chicken meat has low fat among muscle fibers. However, other parts of the carcass have significant fat content, particularly the subcutaneous tissue, abdominal cavity and viscera. Due to its high energy density, fat synthesis and deposition in these tissues are metabolically costly to the birds, in addition of being an undesirable and expensive pathway of dietary nutrient partition.

Consumers today prefer healthier and low-fat foods, and this is why 
Fascina VB, Carrijo AS, Souza KMR, Garcia AML, Kiefer C, Sartori JR
Soybean Oil and Beef Tallow in Starter Broiler Diets poultry companies have attempted to find effective solutions to solve that problem, considering that most oil sources used in poultry diets are offal fat from poultry and other animals and crude vegetable oils.

Very-low density lipoprotein (VLDL) present in the blood is the main indicator of fat deposition due to its correlation with abdominal and total fat content (Grunder \& Chambers, 1985). In addition, low-density lipoprotein (LDL) is the most important factor in the process of arteriosclerosis in humans and animals. The use of vegetable fat sources, such soybean oil (SBO), in animal feeds is an alternative for reducing the content of the those sources that cause arteriosclerosis in animal products.

The objective of the present study was to determine the energy values of different soybean oil (SBO) to tallow $(T)$ ratios and to evaluate their effects on the performance, carcass traits, and serum lipids of starter broiler diets.

\section{MATERIAL AND METHODS}

Two experiments were carried out (digestibility and performance) at the Experimental Poultry Science Lab of the Department of Animal Science of the School of Veterinary Medicine and Animal Science of the Federal University of Mato Grosso do Sul, Campo Grande, MS, Brazil.

\section{Experiment I}

A digestibility trial was used to determine the energy value of SBO and T in the diets of 100 12- to 21-dayold male Ross 308 broilers. Birds were housed in $60 \mathrm{x}$ $50 \times 40 \mathrm{~cm}$ metabolic cages fit with trays previously covered with a plastic sheet to allow excreta collection. Each cage was equipped with a nipple drinker and a trough feeder placed in front of the cage.

The basal diet was formulated with no addition of lipid sources, according to the recommendations of Rostagno et al. (2005) (Table 1). Lipid sources replaced $12 \%$ of the basal diet, and each test diet was composed of $88 \%$ of the basal diet and $12 \%$ of the lipid source. A completely randomized experimental design with five treatments with four replicates of five birds each was applied. Treatments consisted of five different SBO to T ratios (0:100; 25:75; 50:50; 75:25; 100:0).

Birds had a five-day period of adaptation to the experimental diets, and total excreta collection was carried for the next five days. After the adaptation period, ferric oxide $(1 \%)$ was added to all diets in the first and the last days as a marker of the beginning and end of the collection period. Birds received water and feed ad libitum during the entire experimental period. Excreta were collected every 12 hours and stored in a freezer $\left(-10^{\circ} \mathrm{C}\right)$. At the end of the experimental period, the amounts of feed consumed and of feces produced in each experimental unit were recorded.

\begin{tabular}{|c|c|}
\hline Ingredients & Percentage \\
\hline Corn & 64.656 \\
\hline Soybean meal & 31.720 \\
\hline Dicalcium phosphate & 1.800 \\
\hline Limestone & 0.890 \\
\hline DL-methionine (99.0\%) & 0.170 \\
\hline L-lysine $\mathrm{HCl}(78.4 \%)$ & 0.214 \\
\hline Mineral premix ${ }^{1}$ & 0.050 \\
\hline Vitamin premix ${ }^{2}$ & 0.050 \\
\hline Salt & 0.450 \\
\hline Total & 100.000 \\
\hline \multicolumn{2}{|l|}{ Nutritional composition } \\
\hline Metabolizable energy, $\mathrm{kcal} / \mathrm{kg}$ & 2.910 \\
\hline Crude protein, \% & 20.000 \\
\hline Digestible methionine, \% & 0.434 \\
\hline Digestible methionine+cystine, \% & 0.790 \\
\hline Lysine，\% & 1.113 \\
\hline Calcium, \% & 0.878 \\
\hline Available phosphorus, \% & 0.439 \\
\hline \multicolumn{2}{|c|}{$\begin{array}{l}{ }^{1} \text { Content/kg feed: Cu } 9 \text { mg; Zn } 60 \text { mg; I } 1 \text { mg; Fe } 30 \text { mg; Mn } 60 \\
\text { mg. }{ }^{2} \text { Content/kg feed: Vit. A 3,000 IU; Vit. D3 } 500 \text { IU; Vit. E } 5 \text { g; } \\
\text { Pantothenic acid } 4 \text { mg; Niacin } 5 \text { mg; Vit. B6 } 0.4 \text { mg; Vit. B2 } 1 \text { mg; Vit. } \\
\text { B1 } 0.3 \text { mg; Vit. B12 } 3 \text { mcg; Vit. K3 } 0.5 \text { mg; Biotin } 0.015 \text { mg; Se } 0.2 \\
\text { mg; Antioxidant } 1.5 \text { mg. }\end{array}$} \\
\hline
\end{tabular}

Excreta were thawed, pooled by replicate, homogenized, and a $10 \%$ sample was removed and weighed. Samples were then pre-dried in a forcedventilation oven at $55^{\circ} \mathrm{C}$ for 72 hours. Excreta were then exposed to the air to allow them to reach environmental temperature and humidity. Feces were then weighed, ground, and stored for subsequent analysis.

Dry matter and nitrogen analyses of the diets and the excreta were carried out according to the methods described by Silva (1990). Gross energy values were determined using a PARR calorimetric bomb.

Based on the analyses results, metabolizable energy values of the evaluated lipid sources were calculated using the equations proposed by Matterson et al. (1965).

\section{Experiment II}

In this trial, 930 one-day-old male Ross 308 broilers were distributed in a completely randomized experimental design, consisting of five treatments with six replicates of 31 birds each. 
Fascina VB, Carrijo AS, Souza KMR, Garcia AML, Kiefer C, Sartori JR
Treatments consisted of the inclusion of $4 \%$ SBO and $T$ at five different ratios (0:100; 25:75; 50:50; 75:25, and 100:0). Diets contained equal energy and protein levels, were formulated according to the nutritional recommendations of Rostagno et al. (2005) and offered ad libitum in a mash form (Table 2). The energy values of $\mathrm{SBO}, \mathrm{T}$, and their mixtures used for feed formulation were determined in experiment $\mathrm{I}$.

Pens measured $2.38 \mathrm{~m}^{2}$, and were equipped with incandescent lamps for brooding, a bell drinker, and tube feeder. Litter was $10-\mathrm{cm}$ deep and consisted of wood shavings.

Temperature and air relative humidity were monitored by maximum and minimum, dry and wet bulb, and black globe thermometers placed at the birds' height. Temperatures were then used to calculated black globe humidity index (BGHI), according to Buffington et al. (1981). Temperatures were recorded three times daily (8:00 am, 2:00 pm, and 5:00 pm). A lighting program of 24 hours of light was applied.

The parameters weight gain, feed intake, and feed conversion ratio were determined when birds were 21 days of age, and mortality was recorded daily.

At 21 days of age, two birds weighing the same average weight of their replicate were randomly

\section{Soybean Oil and Beef Tallow in Starter Broiler Diets}

chosen for blood collection and subsequent sacrifice to determine carcass yield and abdominal fat percentage. These birds were fasted for 6 hours to reduce feeding effects on blood parameters. A sample of approximately $5 \mathrm{~mL}$ of blood was collected from the ulnar vein using a disposable syringe and $20 \times 5.5$ needle and transferred to test tubes for clotting and to obtain the serum. Total cholesterol (TCH), triglycerides (TRIGL), high-density, low-density, and very-low density lipoproteins (HDL, LDL, VLDL) were determined by spectrophotometry using commercial kits.

Carcass yield was determined as the ratio of eviscerated carcass (with no feet, head and neck) weight to bird body weight. Abdominal fat percentage was determined relative to eviscerated carcass (with no feet, head and neck) weight.

The collected data were submitted to regression analysis at 5\% significance level using the General Lineal Model procedures of SAS (1996) statistical software package.

\section{RESULTS AND DISCUSSION}

\section{Experiment 1}

Table 3 shows the obtained apparent metabolizable

\begin{tabular}{|c|c|c|c|c|c|}
\hline \multirow[t]{2}{*}{ Ingredients } & \multicolumn{5}{|c|}{ Fat source ratios (soybean oil : tallow) } \\
\hline & $0: 100$ & $25: 75$ & $50: 50$ & $75: 25$ & 100:0 \\
\hline Corn & 54.41 & 53.49 & 52.72 & 52.45 & 50.81 \\
\hline Soybean meal $45 \%$ & 34.50 & 35.22 & 35.01 & 34.94 & 34.51 \\
\hline Wheat midds & 0.00 & 0.54 & 1.53 & 1.87 & 3.96 \\
\hline Soybean oil & 0.00 & 1.00 & 2.00 & 3.00 & 4.00 \\
\hline Tallow & 4.00 & 3.00 & 2.00 & 1.00 & 0.00 \\
\hline Vit. and min. premix ${ }^{1}$ & 5.00 & 5.00 & 5.00 & 5.00 & 5.00 \\
\hline Salt & 0.26 & 0.30 & 0.30 & 0.30 & 0.30 \\
\hline Dicalcium phosphate & 0.28 & 0.27 & 0.26 & 0.25 & 0.23 \\
\hline DL-methionine (99.0\%) & 0.45 & 0.40 & 0.40 & 0.41 & 0.40 \\
\hline L-lysine $\mathrm{HCl}(78.4 \%)$ & 0.90 & 0.59 & 0.59 & 0.59 & 0.60 \\
\hline L-threonine $(98.5 \%)$ & 0.20 & 0.19 & 0.19 & 0.19 & 0.19 \\
\hline Total & 100.00 & 100.00 & 100.00 & 100.00 & 100.00 \\
\hline \multicolumn{6}{|l|}{ Nutritional composition } \\
\hline Metab. energy (kcal/kg) & 3.000 & 3.000 & 3.000 & 3.000 & 3.000 \\
\hline Crude protein (\%) & 21.14 & 21.14 & 21.14 & 21.14 & 21.14 \\
\hline Crude fiber (\%) & 3.30 & 3.38 & 3.45 & 3.47 & 3.61 \\
\hline Dig. lysine (\%) & 1.36 & 1.36 & 1.36 & 1.36 & 1.36 \\
\hline Dig. methionine (\%) & 0.53 & 0.53 & 0.53 & 0.53 & 0.53 \\
\hline Dig. methionine+cystine (\%) & 0.97 & 0.97 & 0.97 & 0.97 & 0.97 \\
\hline Dig. threonine (\%) & 0.88 & 0.88 & 0.88 & 0.88 & 0.88 \\
\hline Dig. tryptophan (\%) & 0.22 & 0.22 & 0.22 & 0.22 & 0.22 \\
\hline Linoleic acid (\%) & 1.08 & 1.08 & 1.08 & 1.08 & 1.08 \\
\hline Calcium (\%) & 0.94 & 0.94 & 0.94 & 0.94 & 0.94 \\
\hline Avail. phosphorus (\%) & 0.47 & 0.47 & 0.47 & 0.47 & 0.47 \\
\hline Potassium (\%) & 0.59 & 0.59 & 0.59 & 0.59 & 0.59 \\
\hline Sodium (\%) & 0.22 & 0.22 & 0.22 & 0.22 & 0.22 \\
\hline Chlorine (\%) & 0.20 & 0.20 & 0.20 & 0.20 & 0.20 \\
\hline
\end{tabular}

${ }^{1}$ Content/kg feed: Vit. A 11,000 IU; Vit. D3 2,000 IU; Vit. E 16 mg; Vit. B12 16 mcg; Vit. K3 1.5 mg; Choline 2.60 g; Folic acid 0.40 mg; Pantothenic acid 10.00 mg; Biotin 0.06 mg; Niacin 35.00 mg; Vit. B6 2.00 mg; Vit. B2 4.50 mg; Vit. B1 1.60 mg; Ca 8.62 g; Na 1.20 g; F 29.70 mg; P 3.14 g; Se 0.25 mg; Fe 70.50 mg; Cu 9.00 mg; Mn 0.062 mg; Zn 0.06 mg; I 1.00 mg; Methionine 1.78 g; Growth promoter 0.35 g; Anticoccidial 0.38 g. 
Fascina VB, Carrijo AS, Souza KMR, Garcia AML, Kiefer C, Sartori JR energy (AME) and apparent metabolizable energy corrected for nitrogen (AMEn) values, which linearly increased $(P<0.01)$ as the degree of unsaturation of the lipid ratios increased due to the increase in the participation of SBO in the mixture (Figure 1).

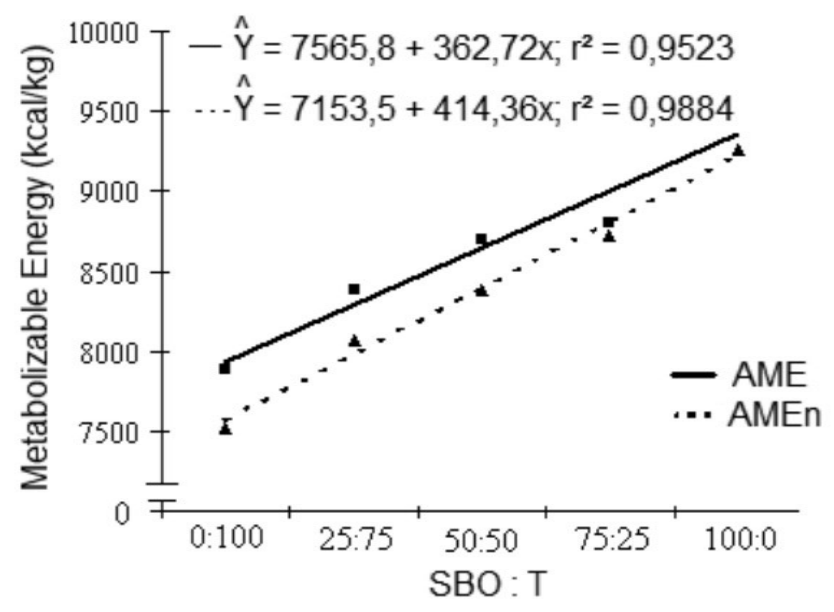

Figure 1 - AME and AMEn values of soybean oil, tallow, and their ratios as determined in 21-day-old male broilers.

According to Freeman (1984), the capacity of young birds producing pancreatic lipase and bile is low, which results in reduced dietary fat digestion and absorption. Nir et al. (1993), studying the development of digestive organs and enzymes in broilers, found that pancreatic lipase activity gradually increased up to 15 days of age, when it reached its maximum.

The linear improvement of energy values of the SBO and $\mathrm{T}$ mixture fed to starter broilers is probably die to the increase in dietary fatty unsaturation degree as, according to Leeson \& Summers (1976), higher concentrations of unsaturated fatty acids improve lipid absorption. Ketels e DeGroote (1989) observed the highest energy values when unsaturated to saturared $(\mathrm{U}: \mathrm{S})$ fatty acid ratio was 2.5. A similar situation was verified by Danicke et al. (2000), but at a U:S ratio of 5.47. Therefore, although the U:S ratio was not determined in the present study, it is possible that the increase of SBO relative to $T$ resulted in a $\mathrm{U}: \mathrm{S}$ ratio

\section{Soybean Oil and Beef Tallow in Starter Broiler Diets}

within the optimal range indicated in literature (Ketels e DeGroote, 1998; Danicke et al., 2000).

When the energy values obtained for SBO individually in the present study were compared to those found in literature, it was observed that our values were similar to those of Junqueira et al. (2005), but higher than the values established by the NRC (1994) and determined by Wiseman et al. (1998), Mossab et al. (2000), Rostagno et al. (2000, 2005), Nascif et al. (2004), and Gaiotto (2004). The same applied to the obtained $T$ values, which were higher than those found by $r$ Ketels \& DeGroote (1989), NRC (1994), Mossab et al. (2000), Danicke et al. (2000), Rostagno et al. (2000, 2005), and Nascif et al. (2004). According to Cullen et al. (1961), fat energy values may be influenced by dietary components, and perhaps this explains why the values obtained in the present experiment were higher than those generally found in literature.

\section{Experiment II}

Maximum, minimum, black globe, and dry bulb temperatures were $30.6 \pm 1.43^{\circ} \mathrm{C}, 27.0 \pm 1.18^{\circ} \mathrm{C}$, $31.53 \pm 1.79^{\circ} \mathrm{C}$, and $29.71 \pm 1.61^{\circ} \mathrm{C}$, respectively. Air relative humidity was $77.03 \pm 18.03 \%$. BGHI was calculated as $82.12 \pm 2.20$, which indicates that birds were submitted to moderate heat stress, which usually causes worse broiler performance.

The inclusion of SBO:T mixture in the diet of 1- to 21-day-old broilers influenced $(P<0.01)$ body weight and weight gain (Table 4) in a quadratic manner, increasing up to the ratio of 65.87:34.13 (Figure 2). Feed conversion ratio was also quadratically affected $(\mathrm{P}<0.01)$, and was reduced down to a 72.25:27.75 ratio (Figure 3). This feed conversion ratio response is related to weight gain as feed intake was not significantly different ( $P>0.05)$ among treatments.

Based on the results of the present study, it may be inferred that was synergy between $T$ and SBO. Feedstuffs rich in unsaturated fatty acids, such as SBO, improve the digestion process by increasing bile secretion for micelle formation, thereby enhancing the absorption of saturated fatty acids, which consequently

Table 3 - Apparent metabolizable energy (AME) and apparent metabolizable energy corrected for nitrogen (AMEn) of soybean oil, tallow, and their ratios as determined in 12- to 21 -day-old broilers.

\begin{tabular}{lllllcr}
\hline Variables & \multicolumn{5}{c}{ Lipid ratios (sovbean oil:tallow) } & \multicolumn{2}{c}{ CV-value } \\
\cline { 2 - 5 } & $\mathbf{0 : 1 0 0}$ & $\mathbf{2 5 : 7 5}$ & $\mathbf{5 0 : 5 0}$ & $\mathbf{7 5 : 2 5}$ & $\mathbf{1 0 0 : 0}$ \\
\hline AME $^{1}{ }^{2}$ & 7.882 & 8.384 & 8.701 & 8.801 & 9.478 \\
AMEn $^{1}{ }^{2}$ & 7.542 & 8.076 & 8.385 & 8.727 & 9.271 & 2.41 \\
\hline
\end{tabular}

1 Linear effect. ${ }^{2}$ Values expressed in $\mathrm{kcal} / \mathrm{kg} .{ }^{3} \mathrm{CV}$, coefficient of variation. 


\begin{tabular}{|c|c|c|c|c|c|c|c|}
\hline \multirow[t]{2}{*}{ Parameters } & \multicolumn{5}{|c|}{ Lipid ratios (soybean oil:tallow) } & \multirow[t]{2}{*}{$p$-value } & \multirow{2}{*}{$\begin{array}{c}\mathrm{CV}^{1} \\
\%\end{array}$} \\
\hline & $0: 100$ & $25: 75$ & $50: 50$ & $75: 25$ & $100: 0$ & & \\
\hline Body weight ${ }^{2}, \mathrm{~g}$ & 847 & 923 & 935 & 921 & 924 & 0.0001 & 2.58 \\
\hline Weight gain ${ }^{2}, g$ & 801 & 877 & 888 & 875 & 881 & 0.0001 & 2.68 \\
\hline Feed intake, g & 1188 & 1266 & 1246 & 1216 & 1245 & 0.182 & 2.86 \\
\hline Feed:gain ${ }^{2}, \mathrm{~g} / \mathrm{g}$ & 1.48 & 1.44 & 1.40 & 1.39 & 1.41 & 0.0002 & 2.03 \\
\hline Livability, \% & 95.99 & 95.48 & 97.58 & 97.42 & 97.58 & 0.567 & 3.32 \\
\hline
\end{tabular}

${ }^{1} \mathrm{CV}$, coefficient of variation. ${ }^{2}$ Quadratic effect.

benefit bird performance, as observed in the present study. Unsaturated fatty acids also cause lower heat increment, and in environmental temperatures above the comfort range, result in higher net energy and better performance (Brue \& Latshaw, 1985).

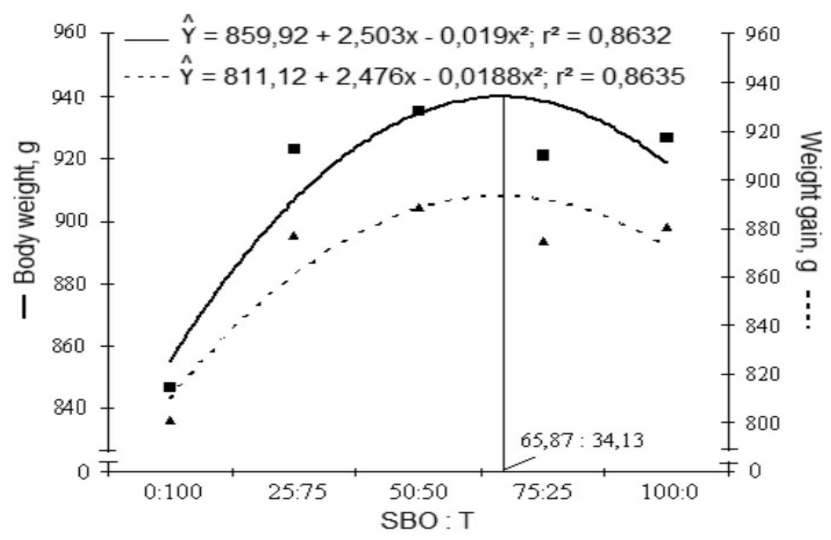

Figure 2 - Body weight and weight gain as a function of different soybean oil to tallow ratios in the diet of 1- to 21-day-old broilers.

The results obtained in the present study are similar to those of Ferreira et al. (2005), who evaluated the inclusion 6\% SBO and $\mathrm{T}$ in grower and finisher Ross broiler diets and observed that the treatment with 75\% SBO promoted higher numerical performance parameter values as compared to the other treatments applied.

On the other hand, our findings are contrasting with those of Tracker et al. (1994), who verified worse performance of 21-day-old broilers fed $\mathrm{T}$ as compared to canola soapstock, and no performance differences in broilers fed either T or acidulated fatty acids derived from crude canola oil. Manilla et al. (1999) obtained higher body weight in broilers fed vegetable oils relative to animal fats.

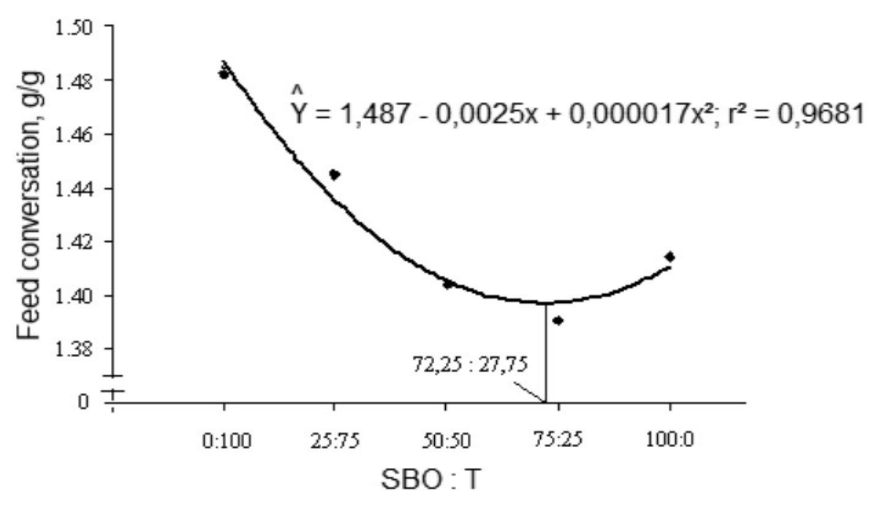

Figure 3 - Feed conversion ratio as a function of different soybean oil to tallow ratios in the diet of 1- to 21-day-old broilers.

Broiler performance at 21 days of age in the present study is different from the reported by Gaiotto et al. (2000), who observed that SBO-oil fed broilers had better performance as compared to those fed acid soybean oil (ASO), T, or a ASO:T mixture (1:1), but no significant differences when SBO was compared to OAS:SBO or SBO:T at a 1:1 ratio.

Table 5 present carcass yield and abdominal fat percentage results of 21-day-old broilers. There were no significant differences $(P>0.05)$ in carcass traits among the evaluated treatments. However, Andreotti et al. (2004), studying the influence of different SBO levels in broilers diets, did not find different carcass yields, but abdominal fat percentage increased as SBO

Table 5 - Carcass yield (CY) and abdominal fat (AbF) percentages of 21-day-old broilers fed diets containing different soybean oil to tallow ratios.

\begin{tabular}{|c|c|c|c|c|c|c|c|}
\hline \multirow[t]{2}{*}{ Parameters } & \multicolumn{5}{|c|}{ Lipid ratios (soybean oil:tallow) } & \multirow[t]{2}{*}{$p$-value } & \multirow{2}{*}{$\begin{array}{c}\mathrm{CV}^{1} \\
\%\end{array}$} \\
\hline & $0: 100$ & $25: 75$ & $50: 50$ & $75: 25$ & $100: 0$ & & \\
\hline$C Y, \%$ & 74.29 & 77.06 & 74.67 & 74.54 & 72.81 & 0.414 & 6.06 \\
\hline$A b F, \%$ & 1.98 & 1.67 & 1.86 & 1.94 & 1.74 & 0.938 & 27.52 \\
\hline
\end{tabular}

${ }^{1} \mathrm{CV}$, coefficient of variation. 
dietary level increased up to $6.84 \%$ in the diet of 56 day-old broilers.

Evaluating the effects of different fat inclusion levels $(0,3$, and $7 \%)$ in the started diet on the performance and carcass yield of 44-day-old broilers, Peebles et al. (1997) concluded that the inclusion of 3 or $7 \% \mathrm{~T}$ between 11 and 21 days of age did not cause any detrimental effect on fat carcass content of 44-dayold broilers. When those authors added those same levels from day 0 to 10 , male carcass yield increased, but this was associated to an increase in abdominal fat content at 44 days of age.

The obtained TRIGL, TCH, HDL, LDL, and VLDL results are presented in Table 6 . There were no HDL differences $(P>0.05)$ among birds fed different lipid ratios. These results are consistent with those of Silva et al. (2001), who did not observe significant variation in the HDL values of broilers fed either vegetable oil or lard. Those authors suggested that this is a positive result for broilers fed animal fat, because high HDL levels may be beneficial as HDL is responsible for the transport of cholesterol from the tissues to the liver, where it metabolized. The same rationale may be applied to the present study as to the HDL values of tallow-fed birds. In addition, tallow HDL values in the present study are higher than those found by Ozdogan and Aksit (2003) and Traker et al. (1994), whereas SBO $\mathrm{HDL}$ values are higher than those obtained by Silva et al. (2001) and Ozdogan and Aksit (2003).

TRIGL values linearly decreased $(\mathrm{P}<0.05)$ as SBO participation in the mixture increased (Trigl $=48.425$ $\left.0.1034 x ; r^{2}=0.99\right)$, and are different from those reported by Ozdogan \& Aksit (2003), who did not find any significant differences between broilers fed vegetable oils or tallow. The TRIGL values of SOB-fed birds in the present study are higher than those in Silva et al. (2001).

TCH levels linearly decreased $(P<0.01)$ as SOB participation increased in the mixtures $(\mathrm{TCH}=169.89$ $\left.0.6112 x ; r^{2}=0.95\right)$. Crespo and Esteve-Garcia (2003) also observed higher total cholesterol level tallow-fed broilers as compared to those fed sunflower and linseed oils, showing that lipid sources rich in polyunsaturated fatty acids reduced total cholesterol levels. On the other hand, $\mathrm{TCH}$ results of the present study contrast with those observed by Ozdogan \& Aksit (2003), who found that tallow promoted lower value as compared to soybean oil. Tracker et al. (1994) did not observe any significant differences in TCH levels between tallow and acidulated fatty acids, individually or combined with glycerol.

As to $L D L$ and VLDL levels, $L D L(P<0.05)$ and VLDL $(P<0.01)$ linearly decreased when SOB dietary levels increasing, demonstrating that lipid sources rich in unsaturated fatty acids reduced the average levels of these lipoproteins, which are implicated in the development of arteriosclerosis in humans and animals $\left(L D L=49.88-0.2125 x ; r^{2}=0.96\right.$ and $\mathrm{VLDL}=10.15-$ $\left.0.0398 x ; r^{2}=0.97\right)$. These data are consistent with the findings of Crespo \& Esteve-Garcia (2003), who observed a decrease in VLDL levels in birds fed sunflower or linseed oil relative to those fed tallow. Ozdogan \& Aksit (2003) also verified lower VLDL values in SOB-fed broilers as compared to tallow.

According to Jiang et al. (1990), cholesterol deposition in the skeletal muscle of chicks stimulated the synthesis of apolipoprotein A-I (ApoA-I), which is characteristic of HDL. ApoA-I activates the enzyme lecithin cholesterol acyltransferase (LCAT), which converts phosphatidylcholine and cholesterol present in chylomicrons and VLDL in cholesterol esters, which are transported to the interior of the HDL molecule. Therefore, in broilers fed diets rich in unsaturated fatty acids, the synthesis of ApoA-I, and consequently of HDL, increase. Therefore, it may be inferred that soybean oil reduces LDL VLDL levels, promoting lower cholesterol content in broilers.

\section{CONCLUSION}

It was concluded that $A M E$ and $A M E n$ values of SBO and T at ratios of 0:100, 25:75, 50:50, 75:25, 100:0 are, respectively, 7.882 and $7.542,8.384$ and 8.076 ,

\begin{tabular}{|c|c|c|c|c|c|c|c|}
\hline \multirow[t]{2}{*}{ Parameters } & \multicolumn{5}{|c|}{ Lipid ratios (soybean oil:tallow) } & \multirow[t]{2}{*}{ p-value } & \multirow{2}{*}{$\begin{array}{c}\mathrm{CV}^{3} \\
\%\end{array}$} \\
\hline & $0: 100$ & $25: 75$ & $50: 50$ & $75: 25$ & 100:0 & & \\
\hline TRIGL1,2 & 48.43 & 45.95 & 43.39 & 40.04 & 38.44 & 0.011 & 17.03 \\
\hline $\mathrm{TCH}^{1}, 2$ & 166.16 & 162.85 & 136.20 & 120.58 & 110.89 & 0.001 & 23.98 \\
\hline $\mathrm{HDL}^{1}$ & 88.42 & 89.06 & 92.78 & 92.81 & 93.45 & 0.418 & 14.27 \\
\hline $\mathrm{LDL}^{1}, 2$ & 48.75 & 47.03 & 37.63 & 34.41 & 28.48 & 0.015 & 40.74 \\
\hline VLDL 1,2 & 10.21 & 9.19 & 7.80 & 7.52 & 6.06 & 0.001 & 23.37 \\
\hline
\end{tabular}

1 Values expressed in $\mathrm{mg} / \mathrm{dL} . .{ }^{2}$ Linear effect. ${ }^{3} \mathrm{CV}$, coefficient of variation. 
Fascina VB, Carrijo AS, Souza KMR, Garcia AML, Kiefer C, Sartori JR
Soybean Oil and Beef Tallow in Starter Broiler Diets

em rações de frangos de corte. Revista Brasileira de Ciência Avícola 2000; 2(3):219-228.

Grunder AA, Chambers JR. Plasma very low density lipoproteins and abdominal fat in broiler chickens: herdabilities and genetic correlations. Poultry Science 1985; 64(1):109.

Jiang Z, Cherian G, Robinson FE, Sim JS. Effect of feeding cholesterol to laying hens and chicks on cholesterol metabolism in pre- and posthatch chiks. Poutry Science 1990; 69:1694-1701.

Junqueira OM, Andreotti MO, Araújo LF, Duarte KF, Cancherini LC, Rodrigues, EA. Valor energético de algumas fontes lipídicas determinado com frangos de corte. Revista Brasileira de Zootecnia 2005; 34(6):2335-2339.

Ketels E, DeGroote G. Effect of ratio of unsaturated to saturated fatty acids of the dietary lipid fraction on utilization and metabolizable energy of added fats in young chicks. Poultry Science 1989; 68:1506-1512.

Leeson S, Summers J. Fat values: The effect of fatty acid saturation. Feedstuffs 1976; 8:26-28.

Leeson S, Summers JD. Nutrition of the chicken. 4th ed. Ontario:University Books; 2001. 591p.

Manilla HA, Husveth F, Nemeth K. Effects of dietary fat origin on the performance of broiler chickens and on the fatty acid composition of selected tissues. Acta Agraria Kaposvariensis 1999; 3(3):375-385.

Matterson LD, Potter LM, Stutz MW, Singsen EP. The metabolizable energy of feed ingredients for chickens. Research Report 1965; 7:3-11.

Mossab A, Hallouis JM, Lessire M. Utilization of soybean oil and tallow in young turkeys compared with young chickens. Poultry Science 2000; 79:1326-1331.

Nascif CCC, Gomes PC, Albino LFT, Rostagno HS. Determinação dos valores energéticos de alguns óleos e gorduras para pintos de corte machos e fêmeas aos 21 dias de idade. Revista Brasileira de Zootecnia 2004; 33(1supl 2):375-385.

National Research Council - NRC. Nutrient Requeriments of Poultry. 9th ed. Washington: Natl. Acad. Press; 1994. 156p.

Nir I, Nitsan Z, Mahagua M. Comparative growth and development of the digestive organs and of some enzymes in broiler and egg type chicks after hatching. British Poultry Science 1993; 34:523532.

Ozdogan M, Aksit M. Effects of the feeds containing different fats on carcass and blood parameters of broilers. Journal of Applied Poultry Research 2003; 12:251-256.

Peebles ED, Brake JD, Latour MA. Broiler performance, yield, and bone characteristcs as affected by starter diet fat level. Journal of Applied Poultry Research 1997; 6:325-330.

Renner R, Hill FW. Factors affecting the absorbability of saturated

Gaiotto JB, Menten JFM, Racanicci AMC, lafigliola, MC. Óleo de soja, óleo ácido de soja e sebo bovino como fontes de gordura 
fatty acids in the chick. Journal of Nutrition 1961; 74:254-258.

Rostagno HS, Albino LFT, Donzele JL, Gomes PC, Oliveira RF, Lopes DC, Ferreira AS, Barreto SLT. Tabelas brasileiras para aves e suínos: composição de alimentos e exigências nutricionais. Viçosa: UFV, Departamento de Zootecnia; 2000. 141p.

Rostagno HS, Albino LFT, Donzele JL, Gomes PC, Oliveira RF, Lopes DC, Ferreira AS, Barreto SLT. Tabelas brasileiras para aves e suínos: Composição de alimentos e exigências nutricionais. 2 ed. Viçosa: UFV, Departamento de Zootecnia, 2005. 186p.

Silva DJ. Análise de alimentos (Métodos químicos e biológicos). 2 . ed. Viçosa: UFV; 1990. 165p.

Silva RR, Oliveira TT, Nagem TJ, Pinto AS, Albino LFT, Almeida MR, Moraes HK, Pinto JG. Efeito hipolipidêmico dos flavanóides naringina e rutina. Archivos Latinoamericanos de Nutrición 2001; 51(3):258-264.

SAS. User's Guide, version 6.4th ed. North Caroline: SAS Institute; 1996. $1686 p$.

Tracker PA, Campbell GL, Xu Y. Composition and nutritive value of acidulated fatty acids, degummed canola oils and tallow as energy sources for starting broiler chicks. Animal Feed Science and Technology 1994; 46:251-260.

Wiseman J, Powles J, Salvador F. Comparison between pigs and poultry in the prediction of the dietary energy value of fats. Animal Feed Science Technology 1998; 71:1-9. 